\title{
Occupational Health and Safety in Biotechnological Processes: A Review and Future Directions
}

\author{
Luma Mirely de Souza Brandão ${ }^{1 *}$, Milson dos Santos Barbosa ${ }^{1}$, Isabela Nascimento Souza ${ }^{1}$, Lays Carvalho de \\ Almeida ${ }^{1}$, Danyelle Andrade Mota ${ }^{1}$, Rafael Buarque de Macêdo Gadêlha ${ }^{2}$, Graziele Áquila de Souza Brandão ${ }^{3}$ \\ ${ }^{1}$ Tiradentes University, Aracaju, Sergipe, Brazil,; ${ }^{2}$ Agamenon Magalhães Hospital, Recife, Pernambuco, Brazil; ${ }^{3}$ Prof. \\ Fernando Figueira Institute of Medicine, Recife, Pernambuco, Brazil
}

\begin{abstract}
An option to change partially or completely conventional chemical methods is a biotechnological process. It enables the development of environmentally friendly and innovative means. The safety of this process has not been fully examined, thus, the lack of awareness about risk management is a great concern. This work aims to elucidate the importance of recognizing, assessing, and controlling potential risks, and developing appropriate risk management to develop bioprocesses safely. For this purpose, qualitative research was carried out through scientific studies and current legislation. Safe development of biotechnological procedures allows for occupational safety throughout the processes. It was observed that control measures should be adopted to obtain a safe work environment for everyone. These measures can be carried out through anticipation, recognition, assessment, and control of existing risks or that may exist in the process. Also, it was found that the involvement of all adequate risk management is fundamental. Therefore, biotechnological processes must be developed safely for workers, the environment, and society.
\end{abstract}

Keywords: Occupational Safety. Occupational Health. Risks. Bioprocesses.

Abbreviations: CLT: Consolidation of Labor Laws; NR: Regulatory Norms.

\section{Introduction}

Processes that involve several stages of transformation through biological agents, such as enzymes, microorganisms, or animal and plant cells, are called bioprocesses [1]. Bioprocesses have attracted a lot of attention due to being a sustainable and innovative alternative for the industry [2]. Thus, scientific and technological research has sought to develop and transform processes and products by biotechnological processes to reduce negative impacts on the environment and the use of fossil fuels. In this context, bioprocesses have been used in several applications, such as for fuel and pharmaceutical products $[3,4]$.

In bioprocesses, the main operations are fermentation, microbial and enzymatic catalysis

Received on 17 September 2020; revised 5 December 2020. Address for correspondence: Luma Mirely de Souza Brandão.Av. Murilo Dantas, 300, Zip Code: 49032-490, Aracaju, SE, Brazil. Phone/Fax: (+5587) 99647-7947. E-mail: luminhamyrele@gmail.com. Article selected from VI International Symposium on Innovation and Technology (SIINTEC).

J Bioeng. Tech. Appl. Health 2021;4(1):43-48.

(C) 2021 by SENAI CIMATEC. All rights reserved.
[5]. Bioprocesses are promising alternatives that are justified by their lower impact on the environment compared to conventional chemical processes. On the other hand, there is little discussion on the safety of their development. It is important to highlight that a good amount of organic solvents for extraction from aqueous solutions can be used in bioproduct processing. Thus, the steps of processing, recycling, control, and safe disposal are necessary for both organic solvents and microorganisms [6].

The use of bioprocess technologies in research and industrial development activities has grown in the world. Risks are directly related to the means and conditions in which operations occur [6]. Because of this, there is a need for special attention to the hygiene and safety in bioprocesses to preserve the health, integrity, and safety of workers and the environment. Along with the accelerated use of this process, a great problem arises, which is the little knowledge and awareness of risk management systems to mitigate the risks [7]. Moreover, the occupational health and safety of such procedures have been little discussed. Therefore, this work aims to elucidate the importance of recognizing, assessing, and controlling potential risks, to develop safer 
bioprocesses for workers, the environment, and society.

\section{Material and Methods}

Research on occupational health and safety in bioprocesses was carried out through important national and international bibliographic databases. The information was collected from scientific studies such as articles and books, published in indexed and specialized journals. Also, Consolidation of Labor Laws (CLT) [8] and Regulatory Norms (NR) [9] were the current legislation used as a basis. Among the NR, NR 9 (Environmental Risk Prevention Program), NR 12 (Machines and Equipment), NR 15 (Unhealthy Activities and Operations), NR 16 (Dangerous activities and operations) e NR 25 (Industrial Waste) were used, since these regulatory norms cover activities carried out in biocatalytic processes. Figure 1 shows the flowchart of the methodology performed.

\section{Results and Discussion}

Occupational health and safety have been widely discussed in several areas in the past 20 years (Figure 2). Figure 2 shows the increase in the numberofarticles whenthekeywords"occupational health" (Figure 2A) and "occupational safety" (Figure 2B) were used separately in the Web of Science database. However, when the keywords "occupational health" and "biotechnological processes" were combined, only 2 articles were found, and when the keywords "occupational safety" and "biotechnological processes" were combined, only 1 article was found. These results showed that little has been discussed about occupational health and safety in biotechnological processes, demonstrating, thus, the need for a greater discussion to preserve the occupational health and safety of workers and the environment.

There are notorious benefits of developing the safety of bioprocesses for industries, companies, workers, and society. This effort promotes the

Figure 1. Qualitative research developed in this work.

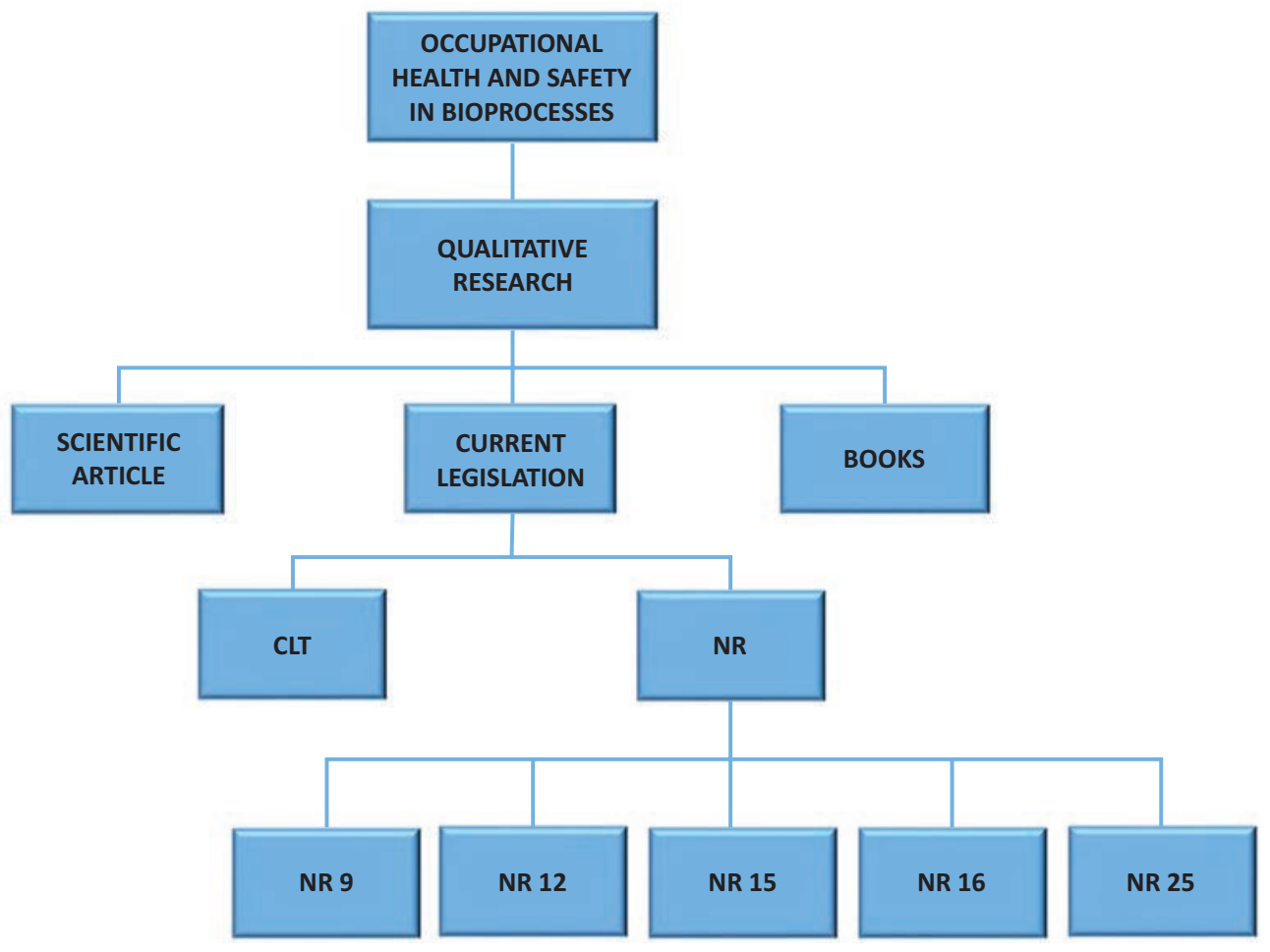


Figure 2. The number of published articles per year between 2000 and 2020 in Web of Science with the keywords: A) "Occupational Health" and B) "Occupational Safety".
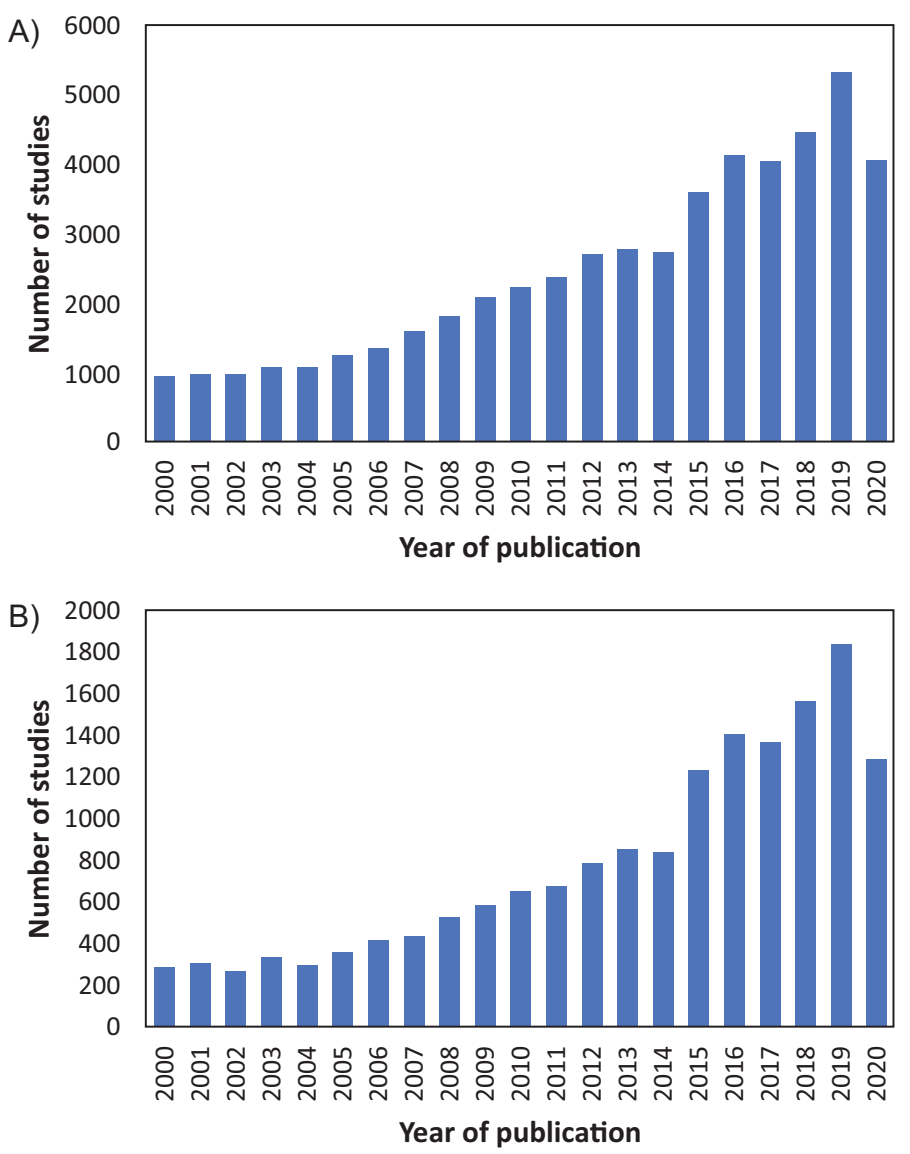

safety of workers throughout the enzymatic and fermentative processes. Among the benefits, the propagation of biotechnological processes is associated with both social and commercial development, which include high-paying jobs, the use of waste, and innovative products that address critical social problems in materials, health, transport, energy, and pollution. Moreover, safer processes lead to greater safety for the worker, through sensors that detect dangerous agents, appropriate protective equipment, and others [10].

To achieve this safety, security measures must be adopted in biotechnological practices. Health risks arising from exposure to biotechnological processes must be eliminated or reduced to guarantee the health and integrity of workers. It is contradictory to say that the development of bioprocesses is responsible, if the health and safety of workers are negatively affected, as well as the environment. This understanding corroborates with NR 9 [11], which explains that employers must develop and implement the Environmental Risk Prevention Program to ensure the health and integrity of workers and the environment with some measures: anticipation, recognition, evaluation, and control of the environmental risks that exist or will exist in the workplace [11].

Despite being an arduous task, the safe and responsible development of bioprocesses and any other industrial process depends on the health and safety of workers and the environment, since both are linked. Also, risks, dangers, and exposures must be understood by everyone involved, to avoid possible accidents that compromise the health and integrity of the worker and the environment. It is important to note that employers 
must assess all risks inherent in the processes to which workers are exposed, and employers must inform their employees [12]. In this sense, NR 9 establishes that all environmental risks present or that may exist in the work environment must be communicated by employers to all employees, as well as possible resources to avoid or mitigate these risks [11]. Moreover, the government must inspect companies/industries, analyzing whether the control of workers' exposures to risks is being carried out properly and there is no damage to workers or the environment [12].

One of the most critical factors that increase the risk is exposure [12]. Thus, there is a need to identify the agents and control exposures to these agents in the work environment, to develop risk management appropriately. In this scenario, employers must be aware and assess the frequency of exposure to risk agents and their magnitude. To establish proper occupational exposure to bioprocesses, it is necessary to obtain information about the monitoring of risk agents [13]. Identification, evaluation, and monitoring are essential to preserving the health of workers and the environment, avoiding unhealthy activities and operations. According to NR 15, activities and operations are considered unhealthy when they are above the tolerance limits (annexes 1, 2, 3, 5,11 , and 12), in which the tolerance limit is the maximum or minimum concentration or intensity related to the nature and the time of exposure to the agent which will not cause damage to the health of the worker during his working life [14].

For the safe and responsible development of bioprocesses, exposure assessment is a very important factor, as mentioned before [13]. However, it is important to emphasize that just assessing the risks is not enough; there is a need for communication about risks between employers, government agencies, and organizations promoting occupational safety and health. Thus, the data of exposure to the risks of processes, when properly disclosed, assist in the decisions about risk management in biotechnological processes [15]. Biotechnological processes can also be safe with adequate knowledge of the procedures and mechanisms used in these processes, in addition to the adoption of control measures, such as eliminating risks, neutralizing risks, training, and hygiene practices.

In bioprocesses, the complexity of risks inherent to the procedures is very large, in addition to the limited knowledge related to safety. Today, the authorities have pointed to the importance of gathering knowledge about the application of bioprocesses and exposure control. It is important to highlight that employers are responsible for proper risk management and preserving worker health [16]. In cases of dangerous activity and operations, NR 16 states that according to article 195 of the CLT, it is using a technical report prepared by an Occupational Physician or Occupational Safety Engineer that the employer is also responsible for the characterization or the mischaracterization of the hazard [17].

Special attention is also needed in the phases of design and use of machines and equipment since they can cause damage to the health and physical integrity of the worker through accidents and illnesses at work. NR 12 has details about occupational safety in regards to machinery and equipment, determining technical references, principles, and protective measures, to guarantee the safety and health of workers. In this sense, NR 12 says that protective measures must be adopted for work on machinery and equipment by the employer, enabling the preservation of health and physical integrity of workers [18].

Another issue that needs special concern is relate to industrial waste that results from processes. NR 25 states that companies are responsible for making decisions that prevent industrial waste from causing damage to workers' health and safety. Also, companies must adopt measures that minimize the generation of waste, preventing this waste from compromising the health and safety of workers and the environment [19].

Regulatory agencies request the execution of good risk management conduct, although some general regulations fit the requirements 
for biological and related processes to develop safe and responsible biotechnological processes. There have been studies reporting the need for the development of safe biotechnological processes, as well as regulations that make this possible. In general, the works show global parameters for the safe exercise of bioprocesses (Figure 3) [5, 6, 20].

In general, the adoption of safety measures, knowledge of the processes, risks, dangers, and the engagement of all involved enable the development of biotechnological processes responsibly and safely. Furthermore, past mistakes can serve as lessons to prevent future problems, which is very advantageous for both scientific and industrial society. Thus, for the development of safer and more responsible biotechnological processes, it is essential that the health and integrity of workers, as well as the environment and society in general, be considered through knowledge and current legislation.

\section{Conclusion}

This work highlighted the importance of developing biotechnological processes safely, guaranteeing the health and safety of workers and the environment. This work also demonstrated the benefits of developing safety regulations for companies, industries, workers, the environment, and society. A safe development is only possible if security measures are adopted via anticipation, recognition, assessment, and control of the risks present in the processes. Moreover, it is necessary that everyone is involved and well informed about risks, dangers, possible ways to mitigate or eliminate such risks, industrial hygiene practices, and adequate supervision. Proper risk management is also a crucial factor for safe biotechnological processes. Therefore, there must be special attention and greater discussion about safety and health in biotechnological processes, to protect the health and well-being of workers, the environment, and society.

\section{References}

1. Shuler ML, Kargi F, Delisa M. Bioprocess engineering: basic concepts. Englewood Cliffs, NJ: Prentice Hall. 2017.

2. Accardi DS, Bubbico R, Palma LD, Pietrangeli B. Environmental and safety aspects of integrated bioRefineries (IBR) in Italy. 2013:32:169-174.

Figure 3. Global parameters for the safe exercise of bioprocesses.

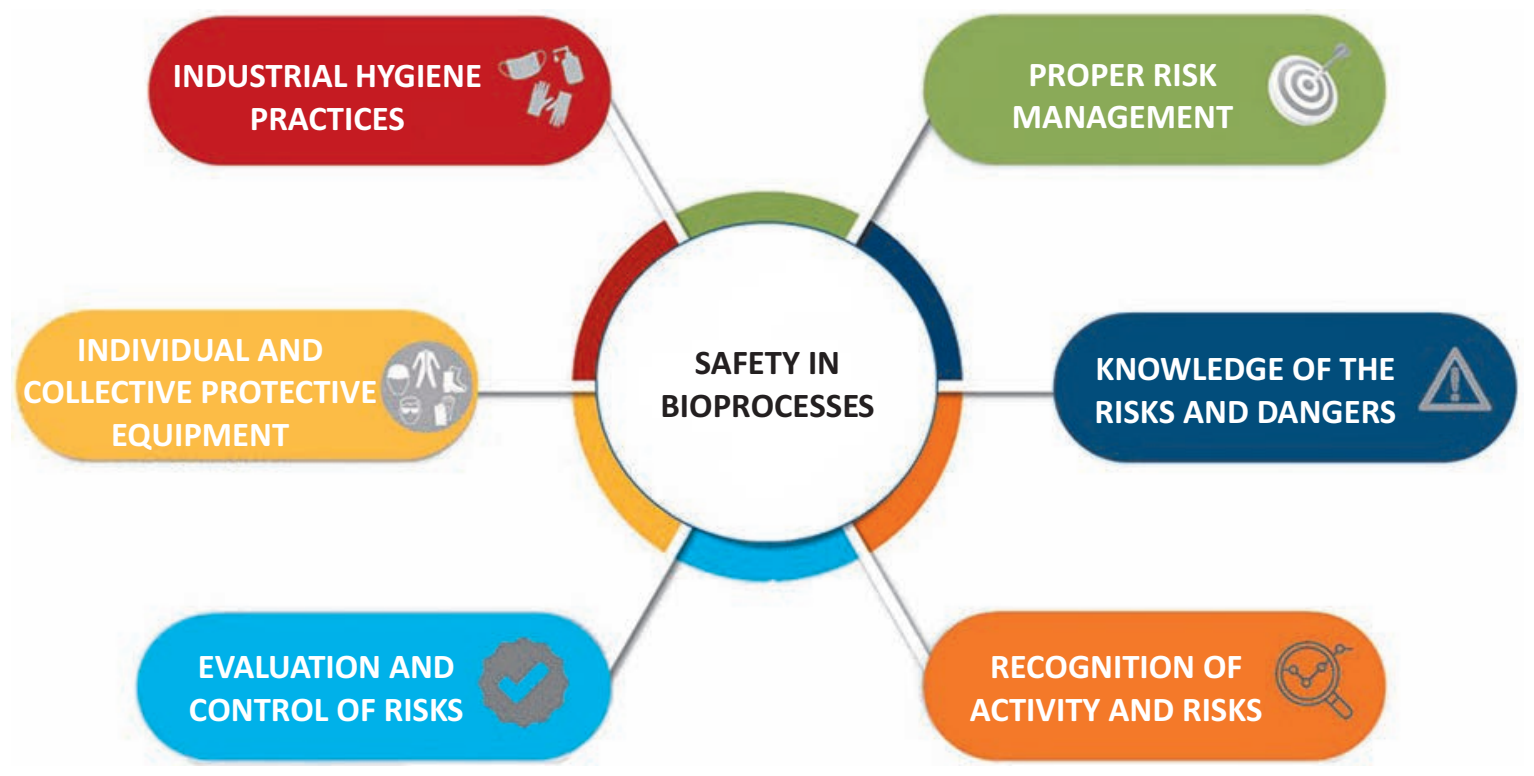


3. Neubauer P, Cruz N, Glauche F, Junne S, Knepper A, Raven M. Consistent development of bioprocesses from microliter cultures to the industrial scale. Engineering in Life Sciences 2013;13:224-238.

4. Takor R. Scale-up of microbial processes: impacts, tools and open questions. Journal of Biotechnology 2012;160:3-9.

5. Olson DG, Mcbride JE, Shaw AJ, Lynd LR. Recent progress in consolidated bioprocessing. Current Opinion in Biotechnology 2012;23:396-405.

6. Moreno VC, Cozzani V. Integrated hazard identification within the risk management of industrial biological processes. Safety Science 2018;103:340-351.

7. Kumar S. Biosafety and biosecurity issues in biotechnology research. Biosafety 2015;4:153.

8. Brasil. Consolidação das Leis do Trabalho. Decreto-lei $\mathrm{n}^{\mathrm{o}} 5.452$, de $1^{\circ}$ de maio de 1943. Available at: < http:// www.planalto.gov.br/ccivil_03/decreto-lei/del5452. htm $>$ Accessed on: 20 July 2020.

9. Brasil. Ministério daEconomia. Normas Regulamentadoras (NR). Available at: < https://sit.trabalho.gov.br/portal/ index.php/seguranca-e-saude-no-trabalho/legislacao-sst/ normas-regulamentadoras? view $=$ default $>$ Accessed on: 26 July 2020.

10. Baram M. Biotechnological research on the most dangerous pathogens: Challenges for risk governance and safety management. Safety Science 2009;47:890898.

11. Brasil. Ministério da Economia. NR 9-Programa de Prevenção de Riscos Ambientais. Available at: < https:/enit.trabalho.gov.br/portal/images/Arquivos SST/SST_NR/NR-09-atualizada-2019.pdf $>$. Accessed on: 26 July 2020.
12. Nauta $M$, Lindqvist $R$, Zwietering $M$. Tools for Microbiological risk assessment. ILSI Europe Report Series 2012.

13. Scarponi GE, Guglielmi D, Moreno CV, Cozzani V. Risk assessment of a biogas production and upgrading plant. Chem Eng Trans 2015;43:1921-1926.

14. Brasil. Ministério da Economia. NR 15- Atividades e Operações Insalubres. Available at: < https://enit. trabalho.gov.br/portal/images/Arquivos_SST/SST NR/NR-15-atualizada-2019.pdf $>$. Accessed on: $2 \overline{6}$ July 2020.

15. Haas CN, Rose JB, Gerba CP. Quantitative microbial risk assessment. John Wiley \& Sons. 1999.

16. Cagno E, Caron F, Mancini M. Risk analysis in plant commissioning: the Multilevel Hazop. Reliability Engineering \& System Safety 2002;77:309-323.

17. Brasil. Ministério da Economia. NR 16- Atividades e Operações Perigosas. Available at: < https://enit. trabalho.gov.br/portal/images/Arquivos_SST/SST NR/NR-16-atualizada-2019.pdf $>$. Accessed on: $2 \overline{6}$ July 2020.

18. Brasil. Ministério da Economia. NR 12- Segurança no Trabalho em Máquinas e Equipamentos. Available at: $<$ https://enit.trabalho.gov.br/portal/images/Arquivos SST/SST_NR/NR-12.pdf>. Accessed on: 26 July 2020.

19. Brasil. Ministério da Economia. NR 25 - - Resíduos Industriais. Available at: < https://enit.trabalho.gov.br/ portal/images/Arquivos_SST/SST_NR/NR-25.pdf $>$. Accessed on: 26 July 2020.

20. Caskey SA, Gaudioso JM, Salerno RM, Wagner SM, Shigematsu M, Risi G, Prat E. Biosafety risk assessment methodology. Sandia National Lab., Albuquerque, NM (United States). 2010. 